\title{
Criminal Description of the Qualifying Norms of Fraud Based on the Analysis of Georgian Court Practice
}

\author{
Jumber Mailashvili \\ School of Law, Grigol Robakidze University, Tbilisi, Georgia \\ Email: jumberlaw@yahoo.com
}

How to cite this paper: Mailashvili, J. (2021) Criminal Description of the Qualifying Norms of Fraud Based on the Analysis of Georgian Court Practice. Open Access Library Journal, 8: e7234.

https://doi.org/10.4236/oalib.1107234

Received: February 9, 2021

Accepted: March 7, 2021

Published: March 10, 2021

Copyright () 2021 by author(s) and Open Access Library Inc.

This work is licensed under the Creative Commons Attribution International License (CC BY 4.0).

http://creativecommons.org/licenses/by/4.0/

\section{(c) (i) Open Access}

\begin{abstract}
During the implementation of the research, the qualifying elements of Article 180 (Fraud) of the Criminal Code of Georgia will be discussed. This paper will refer to the issue of a new definition of a qualifying norm of fraud "in large quantities" made by the Grand Chamber of the Supreme Court of Georgia in 2012, after which different positions about the definition of the norm were formed in the legal literature and court practice. This paper will try to show a different view with regard to this issue. This paper aims to explore and identify the main problems that may arise in the activities of investigative and judiciary bodies in the event that similar cases are qualified according to a new definition of the Grand Chamber of the Supreme Court. This paper will discuss hypothetical cases and examples of comparison, and it will try to substantiate what are the problems that exist in court practice during the application of the qualifying norms with regard to the Article under consideration. This paper will try to highlight the main issues, which, during the application of the norm raise the problem in court practice due to misinterpretation of the norm. The last part of the paper will provide a view about the problems related to the definition and application of special (qualifying) norms of fraud, as well as our views on the introduction of a new qualifying norm.
\end{abstract}

\section{Subject Areas}

Law

\section{Keywords}

CC (Criminal Code), Qualifying Element, Fraud, Property of Another Person, Title to Property, Considerable Damage, Large Quantity, a Group with a Prior Agreement, Organised Group, Official Position 


\section{Introduction}

The aim of the above research is to briefly describe the qualifying norms of Article 180 (Fraud) of the Criminal Code of Georgia as well as the norms interpreted by the court and issues related to the qualification of the action ([1], p. 128). Due to the recent events developed in the country concerning the crimes against property, including the increase of the crime of fraud, it became actual that some norms qualifying fraud were interpreted by the court in a new form that causes different opinions among scientific circles. There are frequent cases when the offender, hidden behind a civil bargain, tries to escape from criminal liability and the result of the illegal action is assessed only as a civil liability or other slightly negligent crime. The Supreme Court of Georgia interpreted one of the cases according to which provision of certain services by people with certain activities when there is no need to provide such services and it occurs only as a means of deception or for disguising the already committed deception, then there is a case of fraud committed by using official position and additional qualifying norm shall be assessed based on the amount of money obtained by criminal action. Here is a quote from the ruling of the Supreme Court: "One of the forms of fraud includes such cases when a medical worker or the leaders of a medical institution prescribe unnecessary treatment to a patient, make a wrong diagnosis in order to show their health condition in a severe form, tell them as if urgent operation was needed while the real situation does not require it. There are cases when a completely healthy person is prescribed treatment or made a surgical operation for the purpose of receiving appropriate amount of money from that patient as the cost for the treatment or the operation made on them ([2], p. 9). The ruling also reads the following: "Similar cases of fraud, in addition to the medical field, can also be found in other areas of activity, such as the construction, certain types of technical services and even in the field of education. Qualification of an action as fraud committed in all such cases cannot be excluded by the circumstance that the offender provided certain services or other activity to the victim in exchange for someone else's money or property seized by him because there was no need for it and the latter is used only as a means of deceiving the victim or disguising the already committed deception" ([2], p. 9). The analysis of these circumstances often makes the qualification of the action controversial, which in turn leads to misinterpretation of the norm and errors in court practice.

The research subject is the description of the norms qualifying fraud, substantiation of the preconditions for the application of each norm as well as the discussion of the issues related to separation from related components in applying some norms qualifying fraud.

\section{Materials and Research Methodology}

In writing this article, there have been analyzed the cases existing in our legal 
practice. This paper also studied the court practice, got introduced to the practice of the Supreme Court of Georgia with regard to the norms qualifying fraud.

As for the Research Methodology, when working on the article there were used analysis, synthesis, comparison, generalization, specification.

\section{General Description of the Norms Qualifying Fraud}

The element qualifying a crime is the circumstance which is considered by the disposition of an Article of a private part of Criminal Code and may aggravate or mitigate liability or punishment.

All dispositions of crime contain a qualifying element. When assessing the qualifying elements and elements of the actual act committed, it becomes clear which crime has been committed ([3], p. 180).

Qualifying elements can be divided into two groups: basic (general component) and additional (special component) qualifying elements ([3], p. 180).

Qualifying norms can be sorted by objective or subjective elements. For example, Article 180, Part 2, Sub-paragraph "A" of the Criminal Code-Fraud committed by a group with a prior agreement and Sub-paragraph " $\mathrm{B}$ " which caused a considerable damage are given according to an objective element, while the subjective element includes the following qualifying circumstances of Part 3 of the same Article: Fraud committed by using the official position and committed repeatedly. Also Sub-paragraph "B" of Part 4, which considers fraud committed by a person who has been convicted twice or more for unlawful possession or extortion of another's property.

General composition is given in the disposition of the first and private part of the Article, i.e. in the general norm of the Criminal Code that describes or names the corpus delicti, which may be considered by another law, normative act giving the description of the act.

The special composition, in the form of additional qualifying elements, is distributed in other parts of the Article (in special norms) and they are applied when the disposition given in the first part inadequately describes the action.

For example, Fraud, i.e. taking property of another person or obtaining of title to the property by deceit for its unlawful appropriation. This part does not specify the fraud committed by a group. Thus, if the crime (fraud) was committed by a group then there should be used Sub-paragraph "A" of Part 2 of Article 180 of the Criminal Code-Fraud committed by a group with a prior agreement.

In the case of the element such as the fraud committed by a group with a prior agreement, should be determined the issue of the prior agreement as well as the existence of the crime committed. It should be noted that in criminal point of view, the existence of a group can be determined only by imputing to the action. In the case where the perpetrator of the fraud is more than one person, but only one of them is arrested, others are not identified and in hiding, the imputation to one person for the crime committed by a group with a prior agreement cannot be qualified as committed by a group with a prior agreement. 


\subsection{Part 2 of Article 180 of the Criminal Code}

\section{1) Fraud committed by a group with a prior agreement}

This action is considered as an aggravating circumstance because in such a case the danger of fraud increases and an objective basis is created to increase the responsibility of all direct participants. This qualifying circumstance refers to the situation where all the executors of the group made a prior agreement on committing fraud. Since the law speaks about a group with a prior agreement, such an action may be committed only by accomplices, in the implementation of which two or more persons (accomplices) participate.

The group with a prior agreement consists of only accomplices, i.e. the persons who are directly involved in the objective component of fraud. Complex accompliceship should not be considered as an act committed by a group with a prior agreement. The accomplices are responsible for the offense according to the function they carried out and in the case of a criminal qualification of an act committed by a group, the act shall be qualified with reference to Article 25 of the Criminal Code. For example, if the accomplice is a person of a group fraud with a prior agreement, their action shall be qualified in the following way: Article 25, Article 180, Part 2, Sub-paragraph “A” of the Criminal Code.

\section{2) Fraud, which caused a considerable damage}

The definition of considerable damage is given in Note 3 of Article 177 of the Criminal Code, according to which "under this Chapter of the Code, a considerable damage shall mean the value of a property(s) worth more than GEL 150". The mentioned issue is based on the assessment of the court and the legislator makes a normative assessment of the damage caused to the victim due to the crime committed. As already noted, a considerable damage shall mean the value of a property(s) worth more than GEL 150 but no more than GEL 10,000 (ten thousand). Professor Mzia Lekveishvili and Professor Nona Todua note that in order a considerable damage to be used as an aggravating circumstance, it is necessary for each victim to face a damage of more than GEL 150 caused by a crime. It is believed that the legislator emphasizes the damage caused to the victim. As it appears, the legislator emphasizes not the total value of a property(s) secretly taken, but the amount of damage caused to a victim individually. [[4], p. 419] They also provide a hypothetical case where a person breaks into somebody's booth and takes property(s) with the value of GEL 160. If it turns out that the owners of this property(s) taken from the booth are different persons whose property valued GEL 80 , the action of each owner shall not be qualified as a considerable damage because damage caused to each owner values only GEL 80 - 80 accompliceship ([4], p. 419).

\subsection{Special Norms of Fraud Considered by Part 3 of Article 180 of the Criminal Code}

\section{1) Fraud committed using an official position}

The subject of fraud using an official position can be both a civil servant and a 
representative of a commercial structure. In the present case, the offender uses his official position in order to take property of another person easily or by deceit, which is not in his lawful possession or administration. This refers to the case when deceit precedes the possession of another person's property. Both the official and the representative of a private organization find it easier to carry out their criminal intent. The Chapter of fraud using official position includes Article 220 (Abuse of powers) and Article 332 (Abuse of official powers) of the Criminal Code and no additional qualifications are required with reference to these Articles. If a person made a fictitious document using his official position and took possession of the property, it would be considered to be the fraud using an official position, but if he could have taken possession of the property by deceit even without a forged document by using his official position and still made a forged document prior to taking possession of the property, then there will be a combination of crimes such as the creation of a forged document and fraud ([5], p. 216).

\section{2) Fraud committed in large quantities}

The concept of "large quantities" is regulated in Note 1 of Article 177 of the Criminal Code and pursuant to legal assessment, "large quantities" shall mean property worth more than GEL 10000. Judgment (Case \#23App-12) made by the Grand Chamber of the Supreme Court of Georgia on November 22, 2012 interpreted Sub-paragraph "b" of Part 3 of Article 180 of CC (Fraud committed in large quantities) unlike the court practice existed before. This paper will provide quotation from the judgment defined by the Grand Chamber: "Therefore, in the case discussed, for the qualification of the action committed in large quantities with a mutual intention and purpose, the key importance should be given to the total value of property (money, property) whether possessed or taken and not to the amount of damage caused to a particular, individual victim" ([6], p. 7). According to such a definition, the qualification of damage caused in large quantities should also be applied in other crimes against property. In the Judgment of the Grand Chamber it was recorded that the existing practice of the Supreme Court of Georgia in the cases of this category should be changed. It is believed that the introduction of new court practice by the Grand Chamber contradicts the definition of a "considerable damage". For example, "A" intended to take the titles to property of various persons by deceit and in order to carry out his criminal intent, he transferred ownership of their real estate into his name in exchange for sending the victims abroad for work. The total value of the real estate with the title to property credited to the names of three victims included GEL 12,000 (twelve thousand). The value of each real estate was GEL 4000 (four thousand). According to the new definition of the Grand Chamber, the value of real estates should be summed up and the action of " $A$ " should be qualified as fraud committed in large quantities. A logical question arises: How should general intention and purpose be determined by one person towards various persons while obtaining title to property by deceit with the total value of proper- 
ty(s)? It is considered that with this explanation it is possible to interpret the real set of crimes artificially, incorrectly as a single continuous crime. Professor Johannes Wessels believes that "important behaviour in criminal point of view, in most cases, consists of a chain of those individual mental acts that are the units of particular social principles. Based on the above mentioned connection of legal social principles, the issue shall be decided whether or not the externally separable acts should be considered as a unity of action and a joint action" ([7], p. 460). It is considered that in the policy of punishment the damage caused due to the crime should not be determined mechanically without identifying the general purpose and intention with the help of the principle of justice in the hypothetical case.

Professor Nona Todua comments on this qualifying norm (Fraud in large quantities): "Attraction of people going to America and issuing fake visas to them does not give us the reason to consider the fraud committed by him at different times as a crime committed with a common intention. There is no general intention but the intention towards a perticular action and the damage caused by that action" ([8], p. 133). Professor Otar Gamkrelidze notes that a continuous crime should be distinguished from a combination of crimes. For instance, in the case of a continuous crime, borrowing books from the library separately is not a repetition of the crime but it is a single intention, and in the case of a repeated crime, each criminal episode includes an independent intention ([9], p. 135). The offender cannot determine in advance how many people (victims) will visit him to help go abroad and also the violation of the title to property of different persons is their individual property rights. Therefore in such cases the damage caused by the action is expressed in the quantity of damage caused individually.

\section{3) Fraud committed repeatedly}

Following the amendments to Article 15 of the Criminal Code, the concept of repeated crime was formed in the following way: "Repeated crime shall mean the commission by a previously convicted person of the crime provided for by the same article of this Code". Repeated fraud shall mean the commission by a previously convicted person of the fraud at least once. In addition to this, Note of Article 177 of the Criminal Code provides for another way of resolving the issue about repeated crimes during the commission of homogeneous crime incidents. Pursuant to Note 2 of Article 177 of CC, repeated actions are considered during the commission of homogeneous crime incidents. The mentioned Note explains that "A crime provided for in Articles 177 - 186 of this Code shall be deemed as having been committed repeatedly if it has been preceded by any of the crimes provided for by these articles and Articles 224, 231, 237 and 264 of this Code. In such a case, a person should have been convicted of any of the crimes provided for in the given articles".

According to the amendment, if a person convicted twice or more for unlawful possession or extortion of another person's property commits fraud, his ac- 
tion shall be qualified under Article 180, Part 4, Sub-paragraph "b" of the Criminal Code and additional qualification with reference to Sub-paragraph "c" of Part 3 of the same Article does not provide the basis since it is a special norm.

Article 15 of the Criminal Code states that "two or more crimes provided for by different articles of this Code shall be considered a repeated crime if so provided for by the relevant article of this Code". Pursuant to Part 2 of the same Article: "a crime shall not be considered as repeated if the person was released from criminal liability for the previous crime in accordance with the law, or if this person's conviction for the previously committed crime was cancelled or expunged".

Thus, a crime shall be considered as repeated, if the person who previously committed the similar crime, must be convicted and the conviction must not be cancelled or expunged.

\subsection{Special Norms of Fraud Provided for in Part 4 of Article 180 of the Criminal Code}

\section{1) Fraud committed by an organised group}

Fraud committed by an organised group is one of the qualifying elements of Article 180 of the Criminal Code, which aggravates punishment for committing the given crime. The existence of the qualifying circumstance in the component of fraud refers to a greater risk of a crime being committed by an organised group than may be in the case of a crime committed by one person or a group with a prior agreement. According to Part 3 of Article 27 of the Criminal Code "a crime shall be considered to have been committed by an organised group if it was committed by a structured group formed and acting jointly within a specific period of time and the member of which united in advance to commit one or several crimes, or the purpose of which is to unlawfully obtain direct or indirect financial or other material benefit".

"In cases provided for by the relevant articles of the Criminal Code, criminal liability for setting up or directing an organised group shall be imposed on the person who created or directed such a group. Liability for all the crimes committed by this group shall be imposed on the same person if the latter intended to commit those crimes. Other participants of an organised group shall bear liability for the participation of the group in cases provided for by the relevant article of the Criminal Code, as well as for the crime in the preparation or commission of which they participated".

Pursuant to the Note of Article 27 of the Criminal Code, for the purposes of paragraph 3 of this Article, a structured group shall be the group that has not been casually set up for immediate commission of a crime and that does not require formal distribution of roles among its members, or continuous membership or a developed structure. Pursuant to Part 3 of Article 27 of the Criminal Code, there must be several conditions to give the qualification to the organization of a group committing fraud: 1) the group must exist within a specific pe- 
riod of time; 2) the group must be acting jointly; and 3) the group must be of a structured form. In addition, it is essential that group members unite in advance to commit one or several crimes, or the purpose of which is to unlawfully obtain direct or indirect financial or other material benefit.

The existence of a group within a specific period of time implies the fact that it is not necessary for it to exist permanently, it may be cancelled even after committing a single crime, so it is not solid.

It is not essential for an organised group to distribute roles formally, nor does the law require the continuity of group membership.

2) Fraud committed by a person who had two or more previous convictions for the appropriation or extortion of another person's property

Pursuant to the Criminal Code of Georgia "A convicted person shall be considered to have a record of conviction from the day of entry into force of the judgment of conviction up to the moment when the record of conviction is cancelled or removed. The record of conviction shall be taken into consideration when making a decision on matters relating to criminal liability, qualification of crime and measures of correction and prevention".

Record of conviction in the component of fraud is considered as a qualifying element. It is therefore necessary to find out whether a person has had his record of conviction cancelled.

The use of qualifying elements in practice existing in the private part of the criminal law is characterized by specificity, which means that it is impossible to use them without establishing certain circumstances. For example, without identifying the criminal it is impossible to use a qualifying element such as fraud committed "repeatedly" or by someone who has been convicted twice or more for the unlawful appropriation or extortion of another person's property. In applying such qualifying circumstances, it is necessary to determine whether a person who committed a crime has been convicted or not. In addition, for the "repeated" qualification it must be clarified whether the commission of fraud was preceded by any of the crimes provided for by Articles 177 and 186 and Articles 224, 231, 237 and 264 of the Criminal Code pursuant to Note 2 of Article 177 of the Criminal Code. In the case where fraud was committed by a person who was convicted twice or more for the unlawful appropriation or extortion of another person's property, it is also necessary to identify whether the perpetrator of the fraud was convicted of the action in the past.

\section{Finding with Analysis}

The correct definition of the qualifying factors of fraud is important in court practice. The correct and objective interpretation of the court practice will contribute to the uniform interpretation of the norm. The fact that the representatives of a medical sector often disguise the cases such as the seizure of another person's property (money) by means of deception, must not be interpreted as official negligence or indifference which also considers light punishment. It is 
also important to separate the crime committed with a single intent from the combination of crimes. In order to prevent the offender from avoiding the expected heavy responsibility by referring to the fact that he made, for example, the pensioners contribute some amount at different times to provide themselves with the "best" insurance, or took some "measures" by deceiving the minors, in this case it would be better that the Criminal Code of Georgia shall be added by Fraud committed, for example, against the persons of a vulnerable category (pensioners, children, people with disabilities, the sick, women) as a qualifying factor.

\section{Conclusion}

Based on the analysis of the above qualifying circumstances, it can be said that the normative content of Article 180, Part 3, Sub-paragraph "b" of the Code (Fraud committed in large quantities) made by the decision of the Grand Chamber of the Supreme Court of Georgian on November 22, 2012 (Case \#23 APP-12) was interpreted differently from the court practice existed before. Pursuant to Disposition of Article 180 of the Code, fraud is taking property of another person or obtaining of title to the property by deceit for its unlawful appropriation. As already mentioned, in obtaining title to the property of another person by deceit, there occurs the violation of the title to property of a certain person individually. Obtaining the title to property by deceit carried out by the perpetrator against several persons, such as attraction of people wishing to go abroad and obtaining the title to property in exchange for the forged visas, is the violation of the goodwill of each individual and should be considered as a real combination of crimes. It is believed that the amount of damage above GEL 10,000 (ten thousand) caused by crime and obtained by mechanical addition must not be considered as fraud in large quantities. With such definition it is possible that a real combination of crimes is artificially and incorrectly treated as a single continuous crime. In addition, the interpretation of Article 180 of Part 2 of Sub-paragraph "b" according to which the legislator is emphasizing the damage caused to the victim by introducing the concept of a considerable crime, in this case a considerable damage of a certain person in the event of a difference in their property, does not make any sense of a considerable damage to be assessed from GEL 150 (one hundred fifty). It is believed that the minimum limit of a considerable damage should be cancelled and moved into the framework of the judicial assessment during the assessment of an item worth up to GEL 10,000 (ten thousand) or title to property. It is also considered that qualifying circumstances should be added to aggravating circumstances of fraud such as fraud committed against a minor or other vulnerable person like a person with a disability or persons of a socially vulnerable category (retired).

\section{Conflicts of Interest}

The author declares no conflicts of interest regarding the publication of this paper. 


\section{References}

[1] Parliament of Georgia, Law (1999) Criminal Code, Legislative Herald of Georgia \#2287.

[2] http://prg.supremecourt.ge/DetailViewCrime.aspx

[3] Kvaratskhelia, R. (2014) Problems with the Qualification of Robbery and Investigation. World of Lawyers, Tbilisi.

[4] Lekvaishvili, M., Todua, N. and Mamulashvili, G. (2016) Private Part of Criminal Code, Book I. Meridiani, Tbilisi.

[5] Kvaratskhelia, R. (2015) Qualification of Some Crimes against Property. World of Lawyers, Tbilisi.

[6] http://www.supremecourt.ge/files/upload-file/pdf/ganmarteba30.pdf

[7] Wessels, J. and Boilke, V. (2010) Criminal Law, General Part, Crime and Its Structure. Tbilisi I. Javakhishvili State University, Tbilisi.

[8] Gamkrelidze, O., Turava, M. and Todua, N. (2004) Comment of Criminal Court practice, Economic Crime. Meridiani, Tbilisi.

[9] Gamkrelidze, O. (2008) Definition of the Criminal Code of Georgia. The Law Book of Georgia and Legislative Herald of Georgia, Tbilisi. 